Agro-Science Journal of Tropical Agriculture, Food, Environment and Extension Volume 18 Number 3 (September 2019) pp. 25-28

ISSN 1119-7455

\title{
GROWTH PERFORMANCE AND NUTRIENT DIGESTIBILITY OF WEST AFRICAN DWARF SHEEP FED HIGH ROUGHAGE DIET CONTAINING Saccharomyces cerevisiae
}

\author{
${ }^{* 1}$ Osita C.O., ${ }^{1}$ Ani A.O., ${ }^{1}$ Ikeh N.E., ${ }^{1,2}$ Oyeagu C.E., ${ }^{1,2}$ Akuru E.A., ${ }^{1}$ Ezemagu I.E. and ${ }^{1}$ Udeh V.C. \\ ${ }^{1}$ Department of Animal Science, University of Nigeria, Nsukka, Nigeria \\ ${ }^{2}$ Department of Livestock \& Pasture Science, University of Fort Hare, \\ Private Bag X1314, Alice 5700, South Africa
}

Corresponding author's email: charles.osita@unn.edu.ng

\begin{abstract}
A twelve-week study was conducted to determine the effects of dietary inclusion of yeast (Saccharomyces cerevisiae) on growth performance and nutrient digestibility of West African dwarf (WAD) sheep. A total of 12 lambs (6 rams and 6 ewes) were randomly allotted to three treatment diets as follows: treatment $I$ was a high roughage diet with no inclusion of S. cerevisiae; treatment II was a high roughage diet with $0.75 \mathrm{~g}$ of $\mathrm{S}$. cerevisiae per $\mathrm{kg}$ of diet; treatment III was a high roughage diet with $1.5 \mathrm{~g}$ of S. cerevisiae per $\mathrm{kg}$ of diet. The chemical composition of the high roughage diet is as follows: dry matter (89.20\%), organic matter (85.87\%), crude protein (13.21\%), crude fibre (16.40\%), ether extract (3.30\%), ash (4.33\%), nitrogen free extract (51.96\%), neutral detergent fibre (45.25\%) and acid detergent fibre (26.62\%). Each group was made up of four replicates with one sheep serving as a replicate. There were significant $(p<0.05)$ differences among treatments in average daily feed intake (ADFI), and average daily weight gain (ADWG) while final body weight $(F B W)$ and feed conversion ratio (FCR) were not significantly $(p>0.05)$ affected. There were significant $(p<0.05)$ differences among treatments in dry matter $(D M)$, organic matter $(O M)$, crude protein $(C P)$, crude fibre (CF), neutral detergent fibre (NDF) and acid detergent fibre (ADF) digestibility coefficients values. Based on these results addition of $1.5 \mathrm{~g}$ of S. cerevisiae per $\mathrm{kg}$ of diet is recommended.
\end{abstract}

Key words: yeast, ruminant, protein, faeces, fibre

\section{INTRODUCTION}

The demand for animal protein in Nigeria has been on the increase because of the rise in human population. The intake of animal protein in Nigeria stands at $3.5 \mathrm{~g} / \mathrm{caput} / \mathrm{day}$. This is still far less than the $35 \mathrm{~g} /$ caput/day recommended by World Health Organization (WHO) (Ironkwe and Amefule, 2008). There is a public and scientific concern about the widespread use of antibiotics and the possibility for transfer of antibiotic resistance to human pathogenic bacteria (Parvez et al., 2006). Also, the presence of antibiotic residues in the meat may adversely affect human consumers. For these reasons the European Union banned the use of antibiotics for non-therapeutic purposes in Jan 01, 2006 (Parvez et al., 2006). It is therefore imperative to find safe alternatives to the use of antibiotics. Yeast and fungal probiotics, such as $S$. cerevisiae and Amaferm (Aspergillus oryzae), have yielded better results in adult ruminants (Fuller, 1999). The most common marketed products for ruminants contain live yeast $(S$. cerevisiae) which is widely used as feed additive because of its beneficial effects on animal performance (Ali and Goksu, 2013; Hassan and Saeed, 2013). Yeasts are most efficient when the rumen is not functioning optimally and when diets are overloaded with easily fermentable energy components or are poor in nutrients. Unlike the destructive action of antibiotics, $\mathrm{S}$. cerevisiae is able to grow rapidly in the rumen and facilitate fiber digestion. Micro-nutrients found in $S$. cerevisiae also stimulate cellulolytic bacteria growth. $S$. cerevisiae in the rumen can utilize the remaining dissolved oxygen and save anaerobic microorganisms from the toxic effect of oxygen. Live yeasts are also able to improve the rumen maturity and stabilize the ruminal $\mathrm{pH}$, thus reducing the risk of acidosis by competing with lactic acidproducing bacteria (McDonald et al., 2002; Chaucheyras-Durand et al., 2008). Supplementation of yeast in the ruminant diet is known to improve feed intake (Robinson and Garrett, 1999), milk production (Abd El-Ghani, 2004), weight gain (Salama et al., 2002), digestion (Jouany et al., 1998), numbers of anaerobic and cellulolytic bacteria (Newbold et al., 1995) and alter the patterns of volatile fatty acids (Arcos-Garcia et al., 2000) or even supply the animal with unknown growth factors (Girard and Dawson, 1995). Against these backdrops, the present study was conducted to determine the effects of dietary inclusion of yeast (S. cerevisiae) on growth performance and nutrient digestibility of West African dwarf sheep. 


\section{MATERIALS AND METHODS}

The study was carried out at the Sheep and Goat Unit of the Department of Animal Science Teaching and Research Farm, University of Nigeria, Nsukka, Enugu State, Nigeria. The study lasted 12 weeks. The yeast (S. cerevisiae) was procured from B.F.P. Dock Road, Felixstowe, U.K.

\section{Experimental Animals and Management}

A total of 12 lambs (6 rams and 6 ewes) with an average weight of $9.98 \mathrm{~kg}$ were used for the study. The lambs were randomly shared into three treatment groups of four sheep each and assigned to high roughage diet. Each group was made up of four replicates with one sheep serving as a replicate. Table 1 shows the composition of the experimental diet. The three dietary treatments were as follows: treatment I was a high roughage diet with no inclusion of S. Cerevisiae; treatment II was a high roughage diet with $0.75 \mathrm{~g}$ of $S$. cerevisiae per $\mathrm{kg}$ of diet; treatment III was a high roughage diet with $1.5 \mathrm{~g}$ of $S$. cerevisiae per $\mathrm{kg}$ of diet. About $500 \mathrm{~g}$ of each diet was given to each lamb daily in the morning and the left over feed was weighed the following morning so as to determine the daily feed intake by each lamb. Water was provided to all the lambs ad libitum. All the lambs were housed individually in pens and the initial weights of the lambs were measured. The weights of the lambs were measured weekly in the morning throughout the experimental period. These were used to calculate the daily weight gain of the lambs. Final body weights of the lambs were measured. Feed conversion ratio was calculated by dividing average daily feed intake with average daily weight gain. Twenty-one days before the experiment all lambs were allowed to acclimatize and the experimental diets were also gradually introduced. The lambs were vaccinated with PPR vaccine and dewormed with Albendazole. The lambs were also injected with Oxytetracycline LA at the rate of $1 \mathrm{ml}$ per 10 $\mathrm{kg}$ body weight to prevent bacterial infections.

\section{Digestibility Trial}

At the end of 12 weeks feeding period two rams were selected from each treatment group for the digestibility trial. Digestibility trial was conducted to determine the digestibility coefficients of the diets using the quantitative collection of faeces. Total collection of faeces were undertaken for seven consecutive days after three days of adapting the growing lambs to the carrying of faecal bags.

Table 1: Percentage composition of the high roughage diet fed to the sheep

\begin{tabular}{ll}
\hline Ingredients & Percentage composition \\
Panicum maximum hay & 60.00 \\
Palm kernel cake & 5.00 \\
Bambara nut waste & 5.00 \\
Brewer's spent grain & 29.00 \\
Salt & 0.50 \\
Vitamins and minerals & 0.50 \\
\hline
\end{tabular}

The quantities of feed offered and the remnants were accurately measured to estimate daily intake during the seven days collection period. Faeces were collected and weighed every morning for each lamb before feed offer. The faeces of each lamb were weighed precisely and about $10 \%$ sub sampled and stored at $-20{ }^{\circ} \mathrm{C}$ in a deep freezer. The faecal samples collected were preserved by wrapping them in polythene and kept in deep freezer. At the end of the collection period, samples of diets and faeces were thoroughly mixed and one sample of each was obtained, properly air dried and in air tight containers for the subsequent chemical analysis. The diets and faecal samples were analyzed for dry matter (DM), organic matter $(\mathrm{OM})$, crude protein $(\mathrm{CP})$, and crude fibre (CF) according to methods of AOAC (1995). The neutral detergent fibre (NDF) and acid detergent fibre (ADF) were determined according to the method of Goering and Van Soest (1970).

\section{Statistical Analysis}

Data collected were subjected to analysis of variance (ANOVA) in a completely randomized design (CRD) as described by Steel and Torrie (1980) using Statistical Package for the Social Sciences (SPSS, 2003). Significantly different means were compared using Duncan's New Multiple Range Test (Duncan, 1955).

\section{RESULTS AND DISCUSSION}

The effect of $S$. cerevisiae supplementation on growth performance and nutrient digestibility of West African dwarf sheep is presented in Table 2. There were significant $(\mathrm{p}<0.05)$ differences among the average daily feed intake (ADFI), and average daily weight gain while final body weight (FBW) and feed conversion ratio (FCR) were not affected significantly $(\mathrm{p}>0.05)$. The ADFI value $(0.30 \mathrm{~kg})$ for sheep fed $1.5 \mathrm{~g} \mathrm{~S}$. cerevisieae per $\mathrm{kg}$ of diet and that $(0.30 \mathrm{~kg})$ of sheep fed $0.75 \mathrm{~g}$ S. cerevisieae per $\mathrm{kg}$ of diet were similar $(\mathrm{p}>0.05)$ but were significantly $(\mathrm{p}<0.05)$ higher than the ADFI value $(0.25 \mathrm{~kg})$ of sheep fed the control diet.

The ADWG value $(0.06 \mathrm{~kg})$ of sheep fed $1.5 \mathrm{~g}$ of $S$. cerevisieae per $\mathrm{kg}$ of diet and that $(0.050 \mathrm{~kg})$ of sheep fed $0.75 \mathrm{~g}$ of $S$. cerevisieae per $\mathrm{kg}$ of diet were similar $(\mathrm{p}>0.05)$. The ADWG value $(0.05$ $\mathrm{kg}$ ) of sheep fed $0.75 \mathrm{~g}$ of $S$. cerevisieae per $\mathrm{kg}$ of diet and that $(0.04 \mathrm{~kg})$ of sheep fed the control diet were also similar $(\mathrm{p}>0.05)$. The ADWG value $(0.06 \mathrm{~kg})$ of sheep fed $1.5 \mathrm{~g}$ of $S$. cerevisieae per $\mathrm{kg}$ of diet was significantly $(\mathrm{p}<0.05)$ higher than the ADWG value $(0.04 \mathrm{~kg})$ of sheep fed the control diet. Tripathi and Karim (2010) reported that yeast culture improved feed intake in growing lambs. The increased feed intake might have been influenced by increase in fibre digestibility stimulated by yeast supplementation (Abd ElGhani, 2004). However, the result obtained in this 
Table 2: Effect of S. cerevisiae supplementation on growth performance and nutrient digestibility of West African dwarf sheep

\begin{tabular}{|c|c|c|c|c|c|}
\hline & Parameter & T1 & $\mathrm{T} 2$ & T3 & SEM \\
\hline \multirow[t]{5}{*}{ Growth Performance } & Average daily feed intake $(\mathrm{kg})$ & $0.25^{b}$ & $0.30^{\mathrm{a}}$ & $0.30^{\mathrm{a}}$ & 0.007 \\
\hline & Average initial weight (kg) & 10.01 & 10.01 & 9.64 & 0.17 \\
\hline & Final body weight & 13.26 & 14.19 & 14.56 & 0.25 \\
\hline & Average daily weight gain $(\mathrm{kg})$ & $0.04^{\mathrm{b}}$ & $0.05^{\mathrm{ab}}$ & $0.06^{\mathrm{a}}$ & 0.003 \\
\hline & Feed conversion ratio & 6.25 & 6.00 & 5.00 & 0.26 \\
\hline \multirow[t]{6}{*}{ Nutrient digestibility } & Dry matter (\%) & $68.21^{\mathrm{b}}$ & $82.49^{\mathrm{a}}$ & $83.90^{\mathrm{a}}$ & 2.17 \\
\hline & Organic matter $(\%)$ & $69.21^{\mathrm{c}}$ & $82.76^{\mathrm{b}}$ & $84.56^{\mathrm{a}}$ & 2.08 \\
\hline & Crude protein $(\%)$ & $72.84^{\mathrm{c}}$ & $84.47^{\mathrm{b}}$ & $86.12^{\mathrm{a}}$ & 1.80 \\
\hline & Crude fibre $(\%)$ & $64.94^{\mathrm{c}}$ & $77.67^{\mathrm{b}}$ & $80.86^{\mathrm{a}}$ & 2.08 \\
\hline & Neutral detergent fibre $(\%)$ & $53.17^{\mathrm{b}}$ & $71.51^{\mathrm{a}}$ & $74.85^{\mathrm{a}}$ & 2.90 \\
\hline & Acid detergent fibre $(\%)$ & $56.30^{\mathrm{b}}$ & $71.62^{\mathrm{a}}$ & $73.19^{\mathrm{a}}$ & 2.31 \\
\hline
\end{tabular}

${ }^{a, b, c}$ Means on the same column with different superscripts differ significantly at $(\mathrm{p}<0.05) ; \mathrm{SEM}=$ Standard error of the means

study is in contrast with Pienaar et al. (2012) who reported that yeast inclusion in the finishing diet of Mutton sheep did not affect feed intake in Mutton Merino lambs. The result of the study agrees with the report of Hassan and Mohammed (2014) who found that the final body weight (FBW) of lambs was not significantly ( $\mathrm{p}>0.05)$ affected by feeding them with diets containing supplementary $S$. cerevisieae. The higher ADWG could be attributed to enhanced feed consumption and absorption of nutrients due to $S$. cerevisieae supplementation. This agrees with Whitley et al. (2009) who reported improvement on the weight gain of growing sheep fed diet supplemented with yeast. However, the result disagrees with the report of Pienaar et al. (2012) which showed that $S$. cerevisieae supplementation did not affect average daily weight gain of animals fed such $S$. cerevisieae -supplemented diet. There were significant ( $\mathrm{p}<$ 0.05 ) differences among treatments in DM, OM, $\mathrm{CP}, \mathrm{CF}, \mathrm{NDF}$ and ADF digestibility coefficients. The DM (83.90\%), NDF (74.85\%) and ADF $(73.19 \%)$ digestibility coefficients for sheep fed 1.5 $\mathrm{g}$ of $S$. cerevisieae per $\mathrm{kg}$ of diet and those of sheep fed $0.75 \mathrm{~g}$ of $S$. cerevisieae per $\mathrm{kg}$ of diet were similar $(\mathrm{p}>0.05)$ but were significantly $(\mathrm{p}<0.05)$ higher than the DM $(68.21 \%) \mathrm{NDF}(71.51 \%)$ and ADF $(56.30 \%)$ digestibility coefficients for sheep fed $0 \mathrm{~g}$ of $S$. cerevisieae per $\mathrm{kg}$ of diet. Sheep fed $1.5 \mathrm{~g}$ of $S$. cerevisieae per $\mathrm{kg}$ of diet had highest ( $\mathrm{p}$ $<0.05)$ OM $(84.56 \%)$, CP $(86.12 \%)$, and $\mathrm{CF}$ $(80.86 \%)$ digestibility coefficients. This was followed by the sheep fed $0.75 \mathrm{~g}$ of $S$. cerevisieae per $\mathrm{kg}$ of diet with OM (82.76\%), CP (84.47\%) and CF $(77.67 \%)$ digestibility coefficients. Sheep fed 0 $\mathrm{g}$ of $S$. cerevisieae per $\mathrm{kg}$ of diet had lowest ( $\mathrm{p}<$ $0.05) \mathrm{OM}(69.21 \%), \mathrm{CP}(72.84 \%)$ and $\mathrm{CF}$ $(64.94 \%)$ digestibility coefficients. The enhanced digestibility due to $S$. cerevisiae supplementation might be improved by fermentation activities of the rumen bacteria, especially the cellulolytic strains. The increased digestibility can be due to stable rumen $\mathrm{pH}$ and removal of oxygen from the rumen in the yeast supplemented group. The stable rumen $\mathrm{pH}$ provides better environment for growth of rumen microbes, especially cellulose degrading bacteria and fungi (Ghazanfar et al., 2015). Addition of $S$. cerevisiae caused a significant improvement in $\mathrm{CP}$ and $\mathrm{CF}$ digestibility (Hassan and Mohammed, 2014). The results of the present study are in line with Gaafar et al. (2009) who reported increase in digestibility of DM and OM due to the addition of $S$. cerevisiae to diets. Increased digestibility of DM, NDF, hemicellulose, and $\mathrm{CF}$ has been reported with supplemental $S$. cerevisiae (Robinson, 2002). Our result support the findings of Haddad and Goussous (2005) who indicated that feeding yeast culture increased the digestibility coefficients of DM, OM, CP, NDF and ADF, which resulted in higher ADWG and better feed efficiency in fattening lambs fed $80 \%$ concentrate diet. In contract to our result, few researchers also reported no effect of yeast on the nutrient digestibility (Tripathi and Karim, 2010).

\section{CONCLUSION}

Results showed that the addition of 0.75 and $1.5 \mathrm{~g}$ of $S$. cerevisiae per $\mathrm{kg}$ of high roughage diet improved ADFI and ADWG. Digestibility of DM, $\mathrm{OM}, \mathrm{CP}, \mathrm{CF}, \mathrm{NDF}$, and ADF were also enhanced by the addition of 0.75 and $1.5 \mathrm{~g}$ of $S$. cerevisiae per $\mathrm{kg}$ of diet. Based on these results, addition of $1.5 \mathrm{~g}$ of $\mathrm{S}$. cerevisiae per $\mathrm{kg}$ of diet is recommended.

\section{REFERENCES}

Abd El-Ghani A.A. (2004). Influence of diet supplementation with yeast culture (Saccharomyces cerevisiae) on performance of Zaraibi goats. Small Ruminant Res., 52, 223-229

Ali B.M. and Göksu S. (2013). Effects of live yeast supplementation on ruminal parameters and lactation performance of dairy cows fed medium or high levels of dietary concentrate. Kafkas Univ Vet FakDerg., 19, $1-57$

AOAC (1995). Association of Official Analytical Chemists, Official Methods of Analysis, (14 ${ }^{\text {th }}$ ed.), Washington, DC, p. 1018

Arcos-Garcia J. L., Castrejon F. A., Mendoza G. D. and Perez-Gavilan E. P. (2000). Effects of two commercial yeast cultures with Saccharomyces cerevisiae on ruminal fermentation and digestion in sheep fed sugar cane tops. Livest. Prod. Sci.,63, 153-157

Chaucheyras-Durand F., Walker N.D. and Bach A. (2008). Effects of active dry yeasts on the rumen microbial ecosystem: Past, present and future. Anim. Feed Sci. Technol., 145, 5-26

Duncan D.B. (1955). Duncan New Multiple Range Test. Biometrics, 11, 1-42 
Fuller R. (1999). Probiotics for farm animals. In: G.W. Tannock (eds.), "Probiotics: A Critical Review," ( pp. 15-22). Horizon Scientific Press, Wymondham, U.K

Gaafar H.M.A., Mohi El-Din A.M.A., Basiuoni M.I. and El-Riedy K.F.A. (2009). Effect of concentrate to roughage ratio and baker's yeast supplementation during hot season on performance of lactating buffaloes. Slovak J Anim Sci., 42, 188-195

Ghazanfar S., Anjum M.I., Azim A. and Ahmed I. (2015). Effects of dietary supplementation of yeast (Saccharomyces cerevisiae) culture on growth performance, blood parameters, nutrient digestibility and fecal flora of dairy heifers. J. Anim. Plant Sci., 25, 53-59

Girard I.D. and Dawson, K.A. (1995). Effect of a yeast culture on growth characteristics of representative ruminal bacteria. J. Anim. Sci., 73, 264

Goering H.K and Van Soest P.J. (1970). Forage Fiber Analysis. Agriculture Handbook, U. S. Department of Agriculture, Washington DC, pp.156- 194

Haddad S.G. and Goussous S.N. (2005). Effect of yeast culture supplementation on nutrient intake, digestibility and growth performance of Awassi sheep. Anim.Feed Sci. Technol., 118, 343-348

Hassan S.A. and Mohammed S.F. (2014). Effects of Saccharomyces cerevisiae supplementation on growth rate and nutrient digestibility in Awassi lambs fed diets with different roughage to concentrate ratios. Biochem. Biotechnol. Res., 2, 37-43

Hassan S.A. and Saeed A.A. (2013). Effect of feeding different levels of dietary protein and addition of baker's yeast (Saccharomyces cerevisiae) on productive parameters of Awassi lambs. J Agric Sci Technol., 3, 484-497

Ironkwe M.O. and Amefule K.U., (2008). Appraisal of Indigenous Pig Production and Management Practices in Rivers State, Nigeria. Journal of Agriculture and Social Research, 8, 1-7

Jouany J. P., Mathieu F., Senaud J., Bohatier J., Bertin G. and Mercier M. (1998). The effects of Saccharomyces cerevisiae and Aspergilus oryzae on the digestion of the cell wall fraction of a mixed diet in defaunated and refaunated sheep rumen.Reprod. Nutr. Dev., 38, 401416
McDonald P., Edwards R.A., Greenhalgh J.F.D and Morgan C.A. (2002). Animal Nutrition. (6 ${ }^{\text {th }}$ eds.), Pearson Education (Singapore) Press Ltd New Delhi, India, pp. 10-15

Newbold C.J. (1995). Microbial feed additives for ruminants. In: R.J. Wallace, A. Chesson (eds.), Biotechnology in Animal Feeds and Animal Feeding. (pp. 259-278).VCH Publishers, New York, USA

Parvez S., Malik K.A., Kang S.A. and Kim H.Y. (2006). Probiotics and their fermented food products are beneficial for health. J. Applied Microbiol., 100, 11711185

Pienaar G.H., Einkamerer O.B., Van der Merwe1 H.J., Hugo A., Scholtz G.D.J and Fair M.D. (2012). The effects of an active live yeast product on the growth performance of finishing lambs.S. Afr. J. Anim. Sci., 42, 657-710

Robinson P.H. (2002). Yeast products for growing and lactating ruminants: Impacts on rumen fermentation and performance. In: Proceedings of the XII International Meeting in Milk and Meat production in Hot Climates (pp. 12). University of Baja California, Mexicali, Mexico

Robinson P.H. and Garrett J.E. (1999). Effect of yeast culture (Saccharomyces cerevisiae) on adaptation of cows to postpartum diets and on lactational performance. J. Anim Sci., 77, 988-999

Salama A.A.K., Caja G., Garin D., Albanell E., Such X. and Casals R. (2002). Effects of adding a mixture of malate and yeast culture (Saccharomyces cerevisiae) on milk production of Murciano Granadina dairy goats. Anim. Res., 51, 295-303

SPSS (2003).Statistical Package for Social Sciences, Windows Version 8. SPSS Inc. USA

Steel R.G.D. and Torrie J.H. (1980). Principles and Procedures of Statistics: A Biometric Approach. ( $2^{\text {nd }}$ ed.) McGraw-Hill Publishers, New York, p. 47

Tripathi M.K. and Karim S.A. (2010). Effect of individual and mixed live yeast culture feeding on growth performance, nutrient utilization and microbial crude protein synthesis in lambs. Anim. Feed Sci. Technol., 155, 163-171

Whitley N.C., Cazac D., Rude B..J., Jackson-O'Brien D. and Parveen S. (2009). Use of commercial Probiotics supplement in meat goat. J. Anim Sci., 87, 723-728 